\title{
Survey dan Pemodelan 3D (Tiga Dimensi) untuk Dokumentasi Digital Candi Borobudur
}

\author{
Deni Suwardhi ${ }^{1}$, Muhammad Mukhlisin ${ }^{1}$, Dendy Darmawan ${ }^{1}$, Shafarina Wahyu Trisyanti ${ }^{1}$, \\ Brahmantara $^{2}$, Yudi Suhartono ${ }^{2}$ \\ ${ }^{1}$ Kelompok Keahlian Penginderaan Jauh dan Sains Informasi Geografis, Institut Teknologi Bandung \\ ${ }^{2}$ Balai Konservasi Borobudur \\ Email :deni@gd.itb.ac.id, mdotmukhlis@gmail.com, dendydar@gmail.com
}

\begin{abstract}
Abstrak : Candi Borobudur merupakan salah satu warisan budaya masa lampau yang sudah ditetapkan oleh UNESCO sebagai Warisan Dunia. Upaya pelestarian Candi Borobudur sebagai salah satu Warisan Dunia (World Heritage) terus dilakukan oleh para pelestari, salah satunya adalah dengan melakukan perekaman secara digital dalam bentuk model 3D (tiga dimensi). Data - data yang disampaikan dalam kajian ini merupakan hasil survey yang terdiri dari (i) survey pemotretan udara menggunakan WUNA (wahana udara nir-awak), (ii) survey pemotretan terestris, (iii) survey terestris menggunakan sensor aktif laser scanner, dan (iv) survey GPS (Global Positioning System) teliti. Kamera yang digunakan dalam pemotretan udara maupun terestris adalah kamera digital format kecil non-metrik yang mempunyai karakteristik parameter orientasi dalam, seperti panjang fokus dan distorsi lensa, yang tidak stabil, sedangkan untuk pemotretan bagian candi yang sulit diambil dari udara seperti patung, relief dan stupa, digunakan teknik foto terestris rentang dekat yang mempunyai prinsip sama dengan teknik foto udara. Salah satu tantangan dalam pengolahan data hasil kajian ini adalah bagaimana teknik Fotogrametri Digital memungkinkan penggabungan keseluruhan foto yang diambil dengan data hasil survey GPS teliti sebagai titik kontrol dan memberi koordinat global pada model 3D yang dihasilkan. Penggabungan tersebut mempunyai tujuan untuk menghasilkan model 3D dengan ragam tingkat kedetilan (Multilevel of Detail). Beberapa objek dengan tingkat kedetilan tinggi, seperti patung, relief dan stupa, dibandingkan dengan model yang dihasilkan dari sensor aktif laser scanner. Setelah model 3D dibuat, tahap berikutnya adalah mengintegrasikan model 3D menjadi Sistem Informasi Geografis 3D untuk analisis lebih lanjut. Kerangka kerja internasional untuk pemodelan kota 3D khususnya obyek Warisan Dunia (World Heritage) CityGML diadopsi untuk tujuan ini.
\end{abstract}

Kata kunci: 3D (tiga dimensi), Warisan Dunia, Borobudur

\begin{abstract}
Borobudur is one of the cultural heritage of the past that has been designated by UNESCO as World Heritage. Conservation efforts Borobudur Temple as one of World Heritage (World Heritage) continue to be made by conservationists, one is to do the recording digitally in the form of $3 \mathrm{D}$ models (three-dimensional). Data - the data presented in this study is a survey consisting of (i) survey aerial photography using WUNA (vehicle air non-crew), (ii) survey of shooting terrestrial, (iii) survey terrestrial uses active sensors laser scanners, and (iv) survey GPS (Global Positioning System) carefully. The camera used in aerial or terrestrial digital camera small format non-metric which has the characteristic orientation parameters in, such as focal length and lens distortion, unstable, whereas for shooting parts of the temple which is difficult to take off the air, such as statues, reliefs and stupas, used techniques terestris photo close range that has the same principle with the technique of aerial photographs. One of the challenges in processing data from this study is how the Digital Photogrammetric techniques allows the incorporation of all photos taken with meticulous GPS survey data as control points and to give the global coordinates of the 3D model generated. The merger has the objective to produce a 3D model with a variety of levels of detail (Multilevel of Detail). Some objects with a high level of detail, such as sculptures, reliefs and stupas, compared to the models generated from the active sensor laser scanner. Once the 3D model is created, the next step is to integrate 3D models into a 3D Geographical Information System for further analysis. International framework for 3D city modeling particular object of World Heritage (World Heritage) City GML was adopted for this purpose.
\end{abstract}

Keywords: 3D (three-dimensional), World Heritage, Borobudur

\section{Pendahuluan}

Sebagai warisan budaya dunia, Candi Borobudur perlu mendapatkan perhatian dalam pemeliharaannya, sebagaimana tertuang dalam perundang-undangan di Indonesia juga dalam arsip internasional (UNESCO):
1. UU RI no 11 thn 2010 tentang Cagar Budaya, Bab VII, Pasal 53 "Pelestarian cagar budaya dilakukan berdasarkan hasil studi kelayakan yang dapat dipertanggungjawabkan secara akademis, teknis, dan administratif."

2. Convention Concerning the Protection of the World 
Cultural and Natural Heritage, November 1972, Section II. National Protection and International Protection of the Cultural and Natural Heritage, Article 5 "... to set up within its territories, where such services do not exist, one or more services for the protection, conservation and presentation of the cultural and natural heritage with an appropriate staff and possessing the means to discharge their functions ..."

Upaya untuk menjaga dan melestarikan bangunan bersejarah ini banyak upaya yang telah dilakukan baik oleh pihak asing maupun dari pihak pribumi. Borobudur telah mengalami serangkaian upaya penyelamatan dan pemugaran dengan proyek terbesar digelar pada kurun 1975 hingga 1982 atas upaya Pemerintah Republik Indonesia dan UNESCO (Soekmono, 1976). Gambar 1 (a) memperlihatkan kegiatan restorasi pertama kali pada tahun 1907-1911 Gambar 1 (b) adalah kegiatan ketika perbaikan salah satu stupa yang setelah tragedi peledakan di tahun 1985. Gambar 1 (c) memperlihatkan tim ahli dari Jerman sedang melakukan pengamatan di sebuah bidang relief Candi Borobudur. Sejak 2011, Pihak Jerman telah memberikan dukungan baik berupa dana maupun tenaga ahli untuk melakukan berbagai kegiatan konservasi Candi Borobudur (regional.kompas.com).

Selain pemugaran dan rekonstruksi, upaya untuk melakukan dokumentasi Borobudur juga telah dilakukan.
Pendokumentasian diantaranya dilakukan dengan cara mengambil gambar atau foto dari masing-masing bagian candi. Pendokumentasian dengan teknik konvensional seperti ditampilkan pada Gambar 1. Untuk itu diperlukan metode dokumentasi yang dapat mendokumentasikan seluruh detail candi dengan baik.

Pada masa lalu, kegiatan pendokumentasian dalam bentuk pengukuran dan pemetaan yang dilakukan oleh para arkeolog, lebih banyak menggunakan teknik yang sederhana seperti dengan pita ukur, alat ukur sudut dan jarak eletronik, penggambaran sketsa ataupun pemotretan. Untuk dapat menghasilkan dokumentasi yang tidak hanya tepat secara visual namun juga secara spasial, diperlukan pengukuran dimensi. Hasil pengukuran dimensi kemudian dapat dituangkan kedalam bentuk gambar profil dan denah 2D (dua dimensi) atau menghasilkan model 3D (tiga dimensi). Salah satu metode yang dapat menjadi alternatif dalam pembuatan dokumentasi Borobudur adalah membuat model 3D digital dengan teknik fotogrametri, khususnya fotogrametri rentang dekat yang dapat digunakan untuk memodelkan bangunan cagar budaya. Teknologi fotogrametri sendiri sebenarnya sudah mulai digunakan untuk pendokumentasian Candi Borobudur pada mas pemugaran 1973-1983. Pada saat itu teknologi ini sudah dikembangkan oleh tenaga-tenaga pemugaran

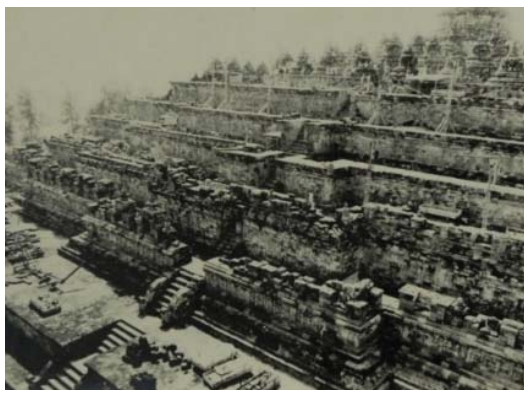

(a)

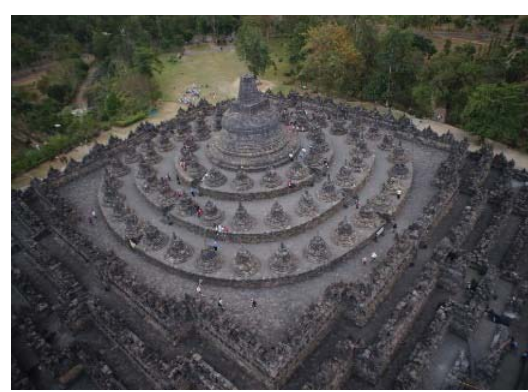

(d)

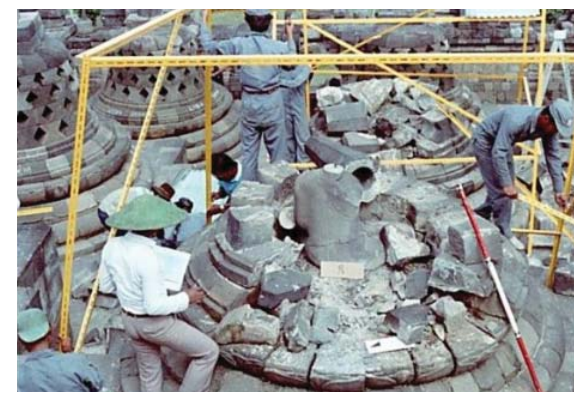

(b)

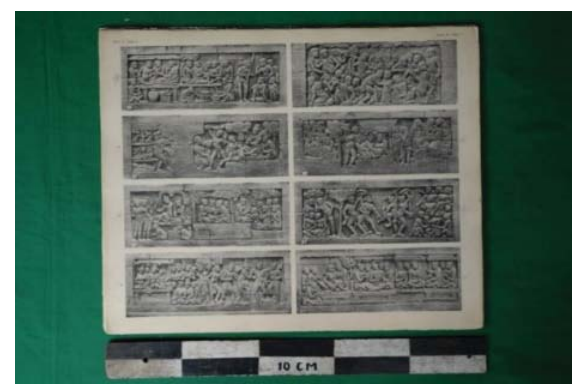

(e)

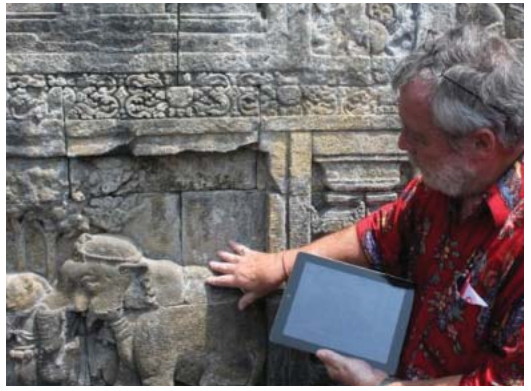

(c)

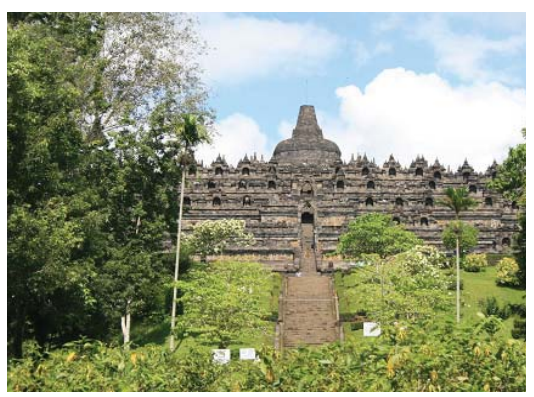

(f)

Gambar 1. Candi Borobudur pada saat pemugaran, Perbaikan salah satu stupa yang setelah tragedi peledakan di tahun 1985, Ahli dari Jerman sedang melakukan pengamatan di sebuah bidang relief Candi Borobudur, Senin (17/11/2014) Kompas.com. Dokumentasi Borobudur yang tersedia saat ini. (sumber : Dokumentasi Balai Konservasi Borobudur). 
Candi Borobudur dengan metode fotogrametri analog, pengambilan foto menggunakan stereo kamera analog dilanjutkan proses untuk digitasi gambar dua dimensinya (2D). teknologi ini kemudian berkembang ke era sekarang yaitu pada era digital.

Dalam rangka menciptakan kesadaran dan pengetahuan umum akan kemampuan teknologi pengukuran dan pemetaan 3D untuk dokumentasi bangunan cagar budaya, maka pada tanggal 28 Oktober 2013 sampai dengan 1 November 2013 di Balai Konservasi Borobudur, Magelang, Jawa Tengah, telah diadakan satu kegiatan lokakarya internasional dengan judul "International Workshop on Reality-Based 3D Modeling for Cultural Heritage and Archeology". Maksud dari lokakarya adalah untuk memperkenalkan kepada para ahli arkeolog dan cagar budaya tentang teknologi berbasis foto (close range photogrammetry dan UAV-photogrammetry) dan berbasis jarak (laser scanning) dalam pemodelan 3D serta aplikasi dan kegunaannya.

\section{Teknologi Survey dan Pemodelan 3D}

\subsection{Teknologi Survey Bangunan Cagar Budaya}

Sebagaimana teknologi di bidang lainnya, teknologi survey dan pemetaan (surta) berkembang semakin pesat pada penghujung abad ke-20. Kecenderungan umum yang tampak pada perkembangan teknologi pemetaan adalah bergesernya peralatan mekanis dan optis ke peralatan elektronis. Sedangkan pemakaiannya pun bergeser dari manual ke otomatis. Perkembangan ini ditunjang oleh makin besarnya peranan teknologi elektronika dan informatika pada pemetaan, mulai dari pengumpulan data, pengolahan, hingga penyajian data dan penyimpanannya.

Sejalan dengan perkembangan teknologi surta, teknologi survey yang biasa digunakan untuk perekaman bangunan cagar budaya, menurut Remondino (2011) bisa dibagi ke dalam 3 kelompok. Kelompok pertama adalah teknologi survey dengan menggunakan sensor aktif, seperti laser scanner, kelompok kedua adalah teknologi survey dengan menggunakan sensor pasif, seperti kamera dan kelompok ketiga adalah teknologi survey konvesional seperti theodolit, EDM, Total Station dan GPS.

\section{a. Metode Survey Klasik}

Seiring dengan bergesernya peralatan mekanis dan optis ke peralatan elektronis maka bermunculanlah peralatan seperti alat ukur jarak elektronis (Electronic Distance Measurement/EDM), alat ukur sudut elektronis (digital theodolit) dan bahkan gabungan dari EDM, digital theodolit dan komputer yang dinamakan ETS (Electronic Total Station) seperti terlihat dalam Gambar 2. Sudut dan jarak yang diperoleh dari pengukuran ETS, kemudian dengan menggunakan persamaan trigonometri dapat diperoleh koordinat 3D $(\mathrm{X}, \mathrm{Y}, \mathrm{Z})$ dari suatu titik relatif terhadap titik tertentu atau titik berdiri alat.

Data yang dihasilkan dari metode survey klasik ini, berupa titik-titik pada detil-detil yang terpilih saja.

\section{b. Metode Survey dengan Sensor Aktif}

Sensor aktif memiliki sumber sinar atau gelombang elektromagnetik sendiri dan sensor juga memiliki kemampuan merekam sinar atau gelombang yang dipantulkan oleh objek yang diukur. Sensor aktif optis banyak digunakan untuk berbagai keperluan, seperti survey dan pemodelan 3D, dan terbagi dalam 3 kategori berdasarkan metode penentuan jaraknya, yaitu yang berbasis pulsa (Time-of-Flight/TOF), fase dan triangulasi. Sensor aktif merekam data geometri

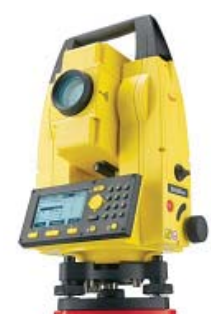

(a)

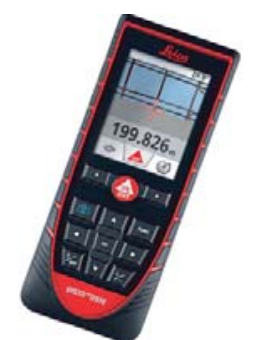

(b)

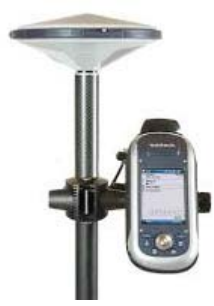

(c)

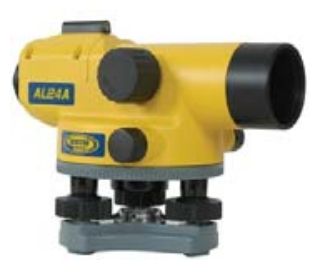

(d)

Gambar 2. Berbagai peralatan ukur konvensional (a) Elektonic Total Station (b) GPS Receiver (c) Distance Meter (d) Waterpass 

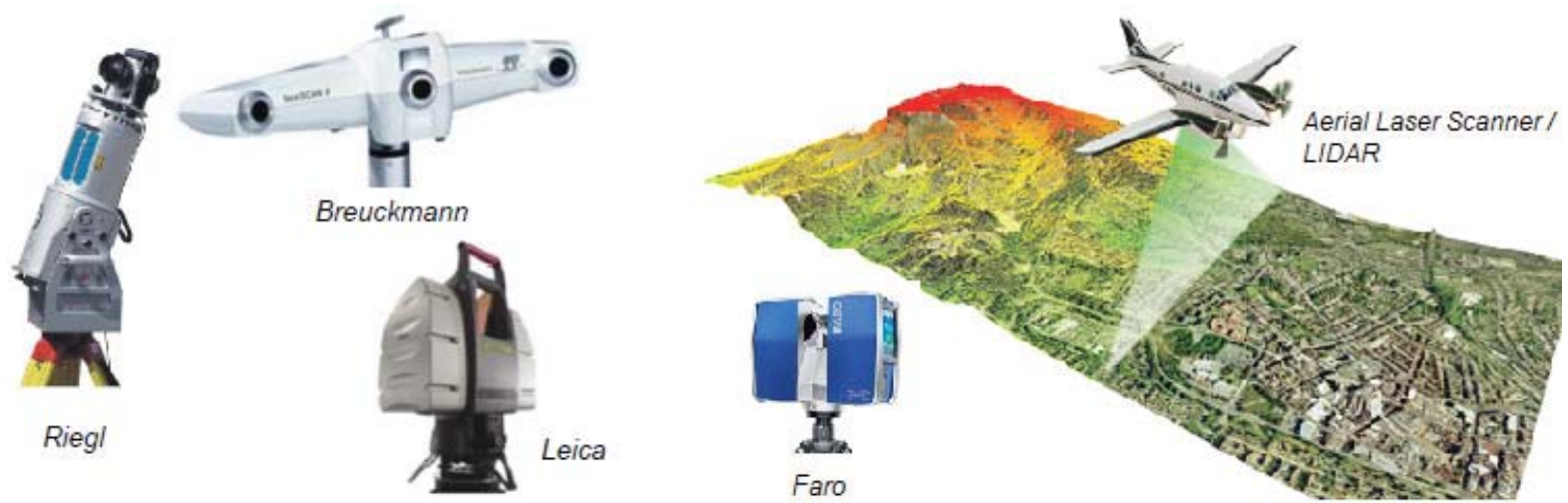

Gambar 3. (a) Sensor Triangulasi (b) Sensor TOF, (c) Sensor Fase, (d) LIDAR

3D dari permukaan objek yang diukur, dalam bentuk kumpulan titik yang juga merupakan koordinat (X,Y,Z) atau sering disebut Point Cloud. Sensor aktif berbasis TOF (pulsa) biasanya mempunyai karakteristik mempunyai jangkauan yang cukup jauh ( s/d $3 \mathrm{~km})$, sedangkan sensor berbasis fase dan triangulasi mempunyai jangkauan menengah ( $\mathrm{s} / \mathrm{d}$ 100 meter) dan jarak dekat ( s/d 3 meter).

Sensor Breuckmann stereoScan seperti yang terlihat pada Gambar 4 (a), merupakan salah satu contoh sensor aktif dengan metode triangulasi dan mempunyai spesifikasi jangkauan sampai 150 cm, Accuracy 5-100 micron dan dilengkapi dengan kamera true color $5 \mathrm{Mpx}$. Gambar 4 (b dan c) adalah contoh sensor aktif dengan metode TOF, yaitu sensor Riegl VZ-1000 dan Leica ScanStation 2. Masing-masing mempunyai spesifikasi jangkauan maksimum 1,4 km, 8 mm @100 m, tidak dilengkapi kamera dan jangkauan maksimum 300 meter, 4mm@50 m, dilengkapi kamera 1Mpx. Gambar 4(d) adalah sensor aktif berbasis fase Faro Photon 120 dengan spesifikasi jangkauan maksimum 120 meter, 2 mm@10 meter, dilengkapi dengan kamera digital.

Laser scanner (hanya tipe Time of Flight) dapat digunakan juga di wahana udara seperti helikopter maupun pesawat bersayap tetap dan umumnya disebut dengan LiDAR, walaupun akan lebih tepat jika dinamakan dengan ALS (Airborne Laser Scanning). Saat ini, wahana udara yang membawa ALS bisa berupa drone atau wahana udara nir-awak (WUNA).

\section{c. Metode Survey dengan Sensor Pasif}

Tidak seperti sensor aktif, sensor pasif tidak mempunyai sumber sinar atau gelombang elektromagentik sendiri, tetapi hanya merekam sinar/cahaya atau gelombang yang dipantulkan oleh objek yang diukur dimana sumber cahaya yang dipantulkannya bisa dari matahari atau sumber cahaya lain seperti lampu blitz. Hasil perekaman sensor ini adalah berupa foto dan untuk mendapatkan data geometri 3D diperlukan pengolahan foto lebih lanjut dengan teknik fotogrametri maupun komputer vision. Konsep pengolahannya adalah dengan menggunakan satu rumus matematika untuk transformasi foto $2 \mathrm{D}$ menjadi geometri 3D. Dibutuhkan paling sedikit dua foto sehingga geometri 3D dari objek bisa dihitung dengan menggunakan rumus transformasi proyeksi perspektif.

Gambar 4 (a) sd (b) memperlihatkan jenis kamera yang sering digunakan dalam fotogrametri, mulai dari kamera

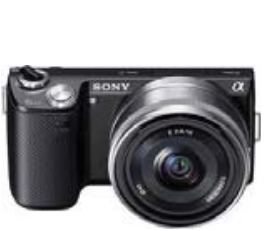

(a)

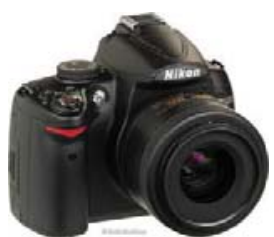

(b)

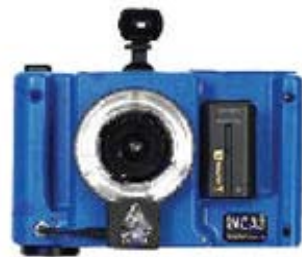

(c)

Gambar 4. Kamera yang digunakan dalam pengambilan data.(a) Sony NEX-5N,(b) Nikon D5000,dan (c) Nikon D5100.

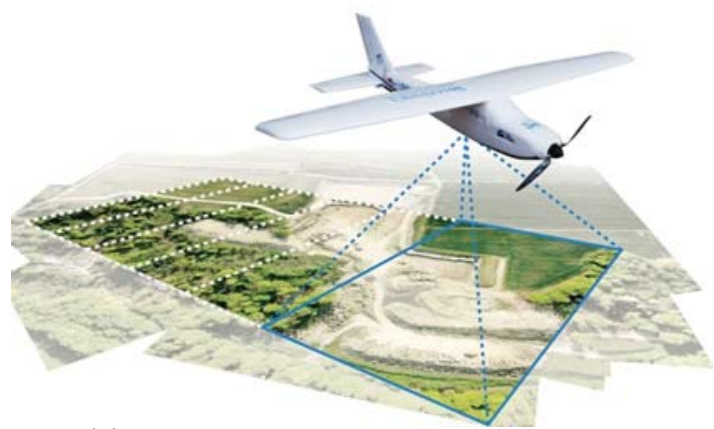



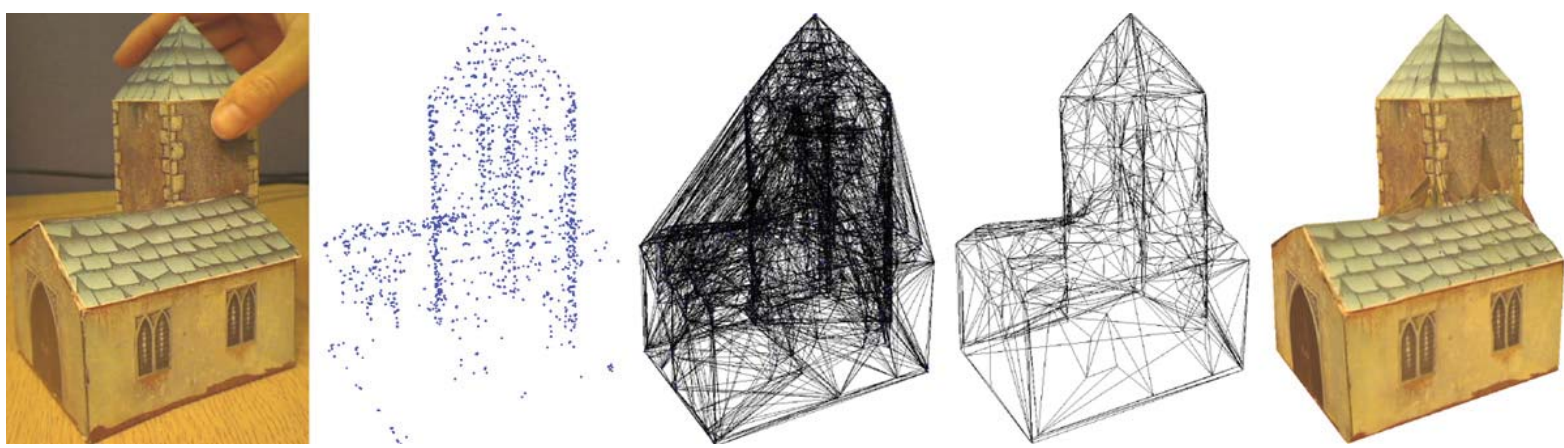

Gambar 5. Ilustrasi Pemodelan 3D Objek dari Point Cloud menjadi Data Terstruktur

konsumer, prosumer, profesional dan metrik. Untuk survey teliti sangat disarankan menggunakan kamera metrik yang bisa menghasilkan akurasi sampai dengan $1: 200,000$.

\subsection{Pemodelan 3D Bangunan Cagar Budaya}

Dalam bidang komputer grafik, pemodelan 3D adalah proses membangun representasi secara matematis dari setiap permukaan tiga-dimensi suatu objek menggunakan perangkat lunak khusus. Jika yang dimodelkan adalah objek nyata, maka objek tersebut diukur atau diamati dengan teknologi survey yang telah diuraikan di bagian 2.1. Data berupa point cloud sering disebut data tidak terstruktur, sementara representasi model 3D biasanya disebut sebagai data terstruktur seperti model solid (contoh: Constructive Solid Geometry) maupun model permukaan (contoh: Polygonal Mesh). Dengan demikian, bisa juga dikatakan bahwa pemodelan 3D adalah mengubah data tidak terstruktur menjadi terstruktur.

\section{Tahapan Pelaksanaan Kajian}

Dalam pembuatan model digital 3D Borobudur ada dua data utama yang digunakan. Data pertama yaitu data foto udara format kecil yang diambil dengan menggunakan wahana udara tanpa awak berupa multicopter yang dikendalikan dengan remote control. Sedangkan yang kedua adalah data foto rentang dekat yang diambil secara langsung dengan menggunakan kamera digital. Kemudian dua data tersebut dibentuk model 3D dengan menggunakan teknik fotogrametri.

Setelah didapatkan model 3D dari masing-masing
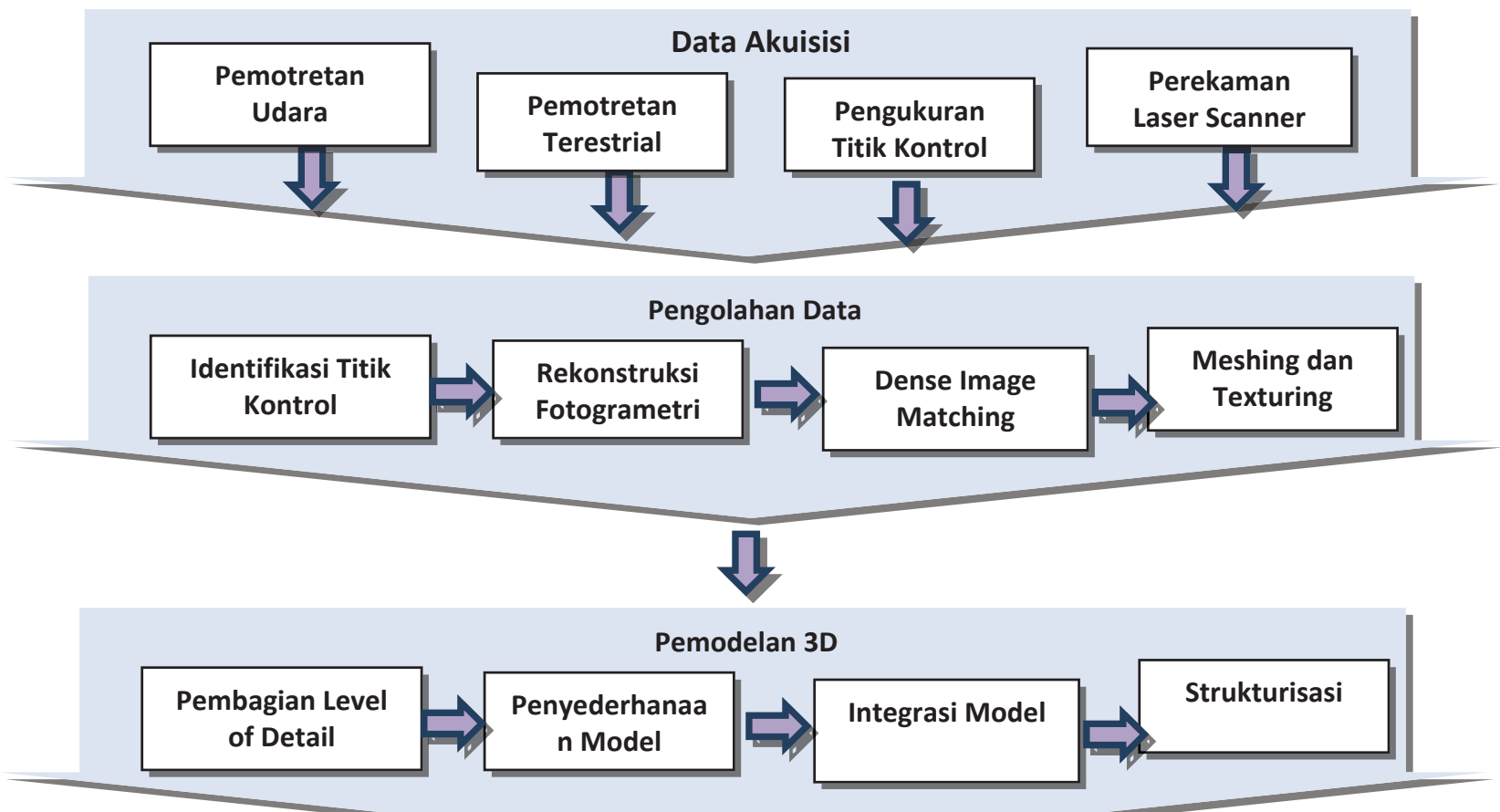

Gambar 6. Diagram alir pengolahan data penelitian. 

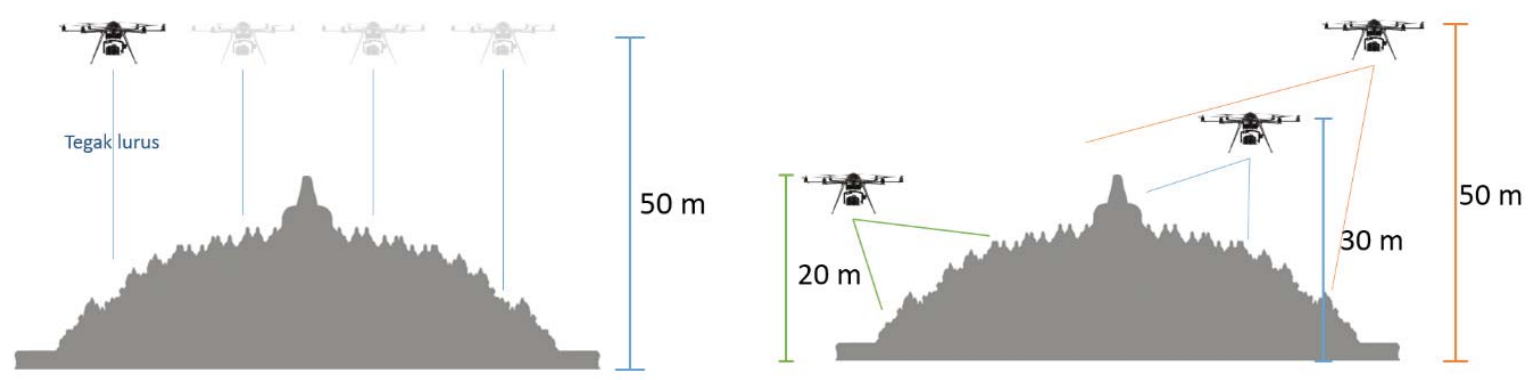

Gambar 8. Akuisisi data foto udara format kecil secara vertikal dan miring

data diatas kemudian disederhanakan sehingga menjadi beberapa tingkat kedetilan. Dengan menggunakan koordinat titik sekutu yang diketahui di kedua model (model hasil foto udara dan model hasil foto rentang dekat) kemudian kedua model tersebut diintegrasikan sehingga menjadi model yang utuh. Untuk lebih jelasnya pada gambar 6 disajikan diagram alir tahapan kerja yang digunakan dalam Lokakarya.

\subsection{Akuisisi Data}

Dalam penelitian kali ini, model 3D Borobudur dibuat dengan menggunakan data foto yang berasal dari pemotretan objek secara langsung tepatnya di candi Borobudur, Magelang, Jawa Barat. Data tersebut diambil pada tanggal 7-10 Oktober 2013, 28-31 Oktober 2013 dan 5-8 Januari 2014. Pengambilan data dibagi menjadi dua bagian yaitu pemotretan foto udara fomat kecil serta pemotretan rentang dekat untuk relief dan stupa.

\subsubsection{Pemotretan Udara}

Pengambilan foto udara Borobudur dilakukan dengan bantuan wahana udara tanpa awak quadcopter. Wahana udara ini memiliki empat buah baling-baling yang berjarak identik dari pusatnya. Untuk keperluan pengambilan data sebuah kamera dilekatkan di badan wahana tersebut. Kemudian wahana tersebut dekendalikan dari jarak jauh hingga mencapai posisi yang cukup untuk pengambilan dalam pembuatan model. Dalam hal ini posisi kamera sangat mempengaruhi model yang akan dihasilkan. Oleh karena itu jalur terbang dari wahana tersebut dibuat sedemikian rupa sehingga dapat mencakup semua bagian candi Bororbudur secara keselurhan dengan cara membagi jalur terbang menjadi beberapa bagian.

Pengambilan data foto udara format kecil ini dibagi menjadi dua bagian yaitu secara vertikal dan secara sendeng (oblique). Pengambilan data secara vertikal dilakukan dengan cara memposisikan sumbu utama kamera tegak lurus dengan permukaan candi seperti terlihat pada Gambar 8a. Sedangkan pengambilan foto dengan cara sendeng dilakukan dengan cara memposisikan kamera sedemikaian rupa sehingga terbentuk sudut antara sumbu utama kamera dan pemukaan bumi. Dalam pengambilan foto secara sendeng, posisi wahana udara dalam pengambilan data foto dibuat menjadi beberapa posisi ketinggian. Posisi ketinggian ini diantaranya adalah 20 meter, 30 meter dan 50 meter diatas permukaan tanah seperti terlihat pada Gambar 8b.
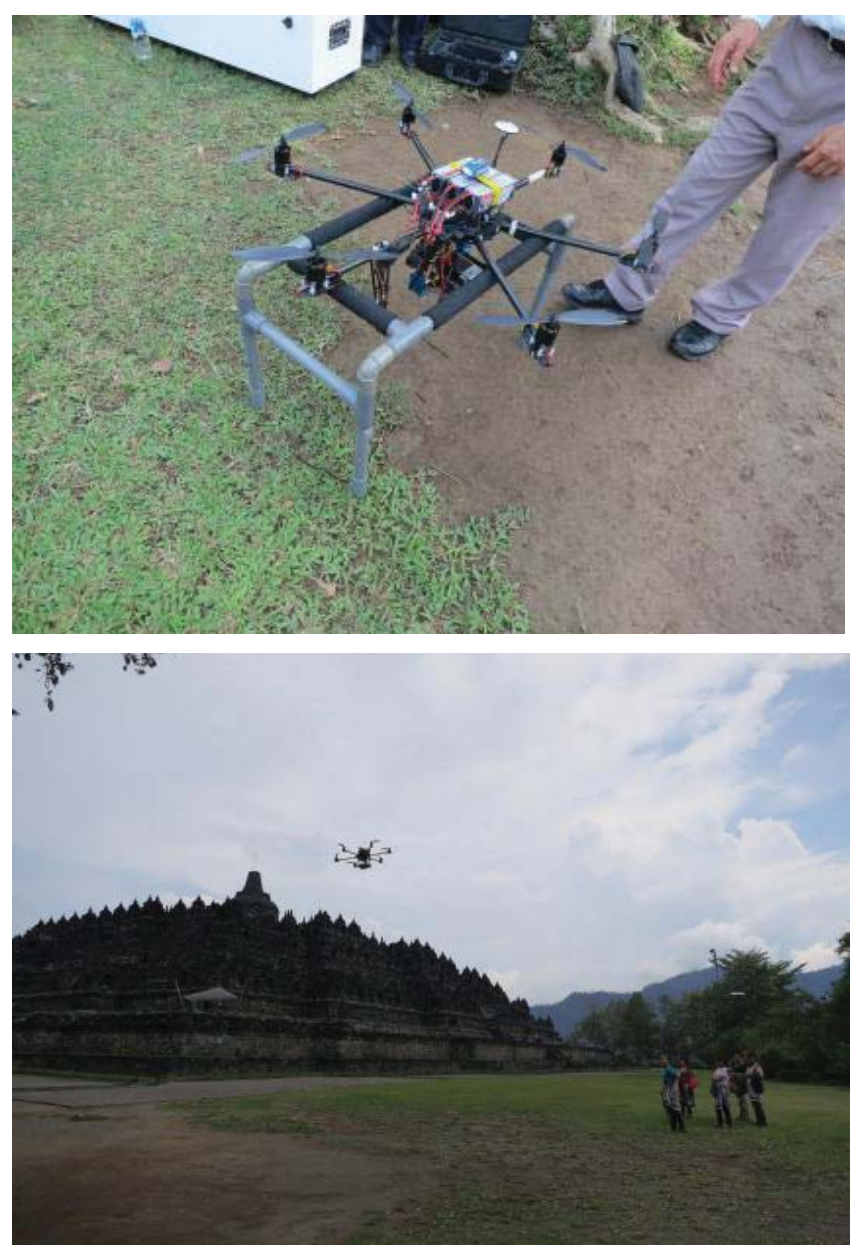

Gambar 9. Pelaksanaan Pengambilan Foto Udara 

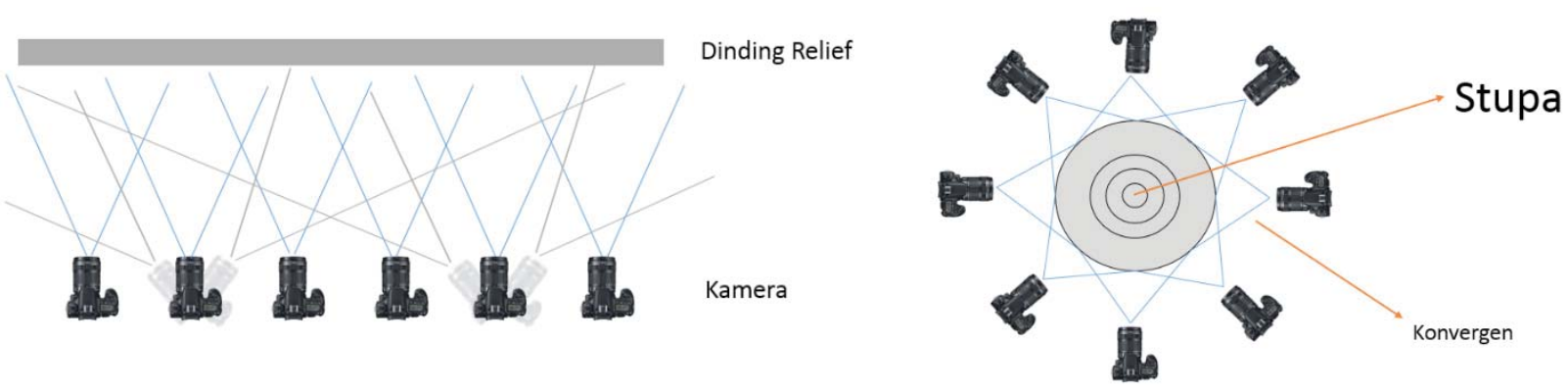

Gambar 10. Geometri pengambilan (a) data relief dan (b) stupa.

Kamera yang digunakan adalah kamera digital Sony NEX-5N yang merupakan kemera format kecil dengan resolusi 4912x3264 piksel. Kamera ini menggunakan CMOS sebagai sensornya dengan ukuran 23.4x15.6 mm. Sebagian besar pengambilan gambar dilakukan dengan menggunakan mode prioritas kecepatan rana (shutter speed) yang diatur pada 1/1250 detik dengan bukaan rana bervariasi antara $f / 3.2$ - $f / 3.5$ untuk siang hari dan $f / 7-f / 8$ untuk pagi hari.

\subsubsection{Pemotretan Foto Rentang Dekat}

Pengambilan data foto rentang dekat dilakukan dengan cara mendatangi objek secara langsung dengan mengunakan kamera Digital Single-lens Reflex (DSLR). Ada dua kamera yang digunakan dalam pengambilan data rentang dekat diantaranya Nikon D5000 dengan lensa 24mm dan Nikon D5100 dengan lensa 18mm.

Pengambilan gambar dilakukan dengan mode prioritas bukaan rana (aperture priority) yang diatur pada f/11 dan kecepatan bukaan lensa bervariasi antara 1/30 detik hingga 1/80 detik. Pada saat pengambilan gambar dipastikan gambar diambil dengan menggunakan resolusi tertinggi yang paling mungkin agar menghasilkan gambar dengan kualitas yang baik.

Untuk pengambilan data relief, geometri pengambilan data berbentuk lurus dengan overlap sekitar $80 \%$. Dalam pengambilan data posisi kamera tegak lurus dengan bidang relief yang akan diambil datanya. Untuk memperkuat geometri kamera dibeberapa tempat kamera diputar sekitar $35^{\circ}$ sehingga dapat mencakup area disekitarnya. Untuk lebih jelasnya perhatikan Gambar 10 (a).

Untuk pengambilan data stupa, geometri pengambilan datanya berupa lingkaran konsentris. Dengan sumbu utama kamera tegak lurus dengan dinding stupa. Pengambilan data dilakukan dengan dua basis dengan basis pertama mencakup 3/4 bagian bawah stupa dan basis kedua mencakup $3 / 4$ bagian atas stupa. Basis bawah stupa diambil dengan posisi kamera miring (landscape) sedangkan basis atas stupa diambil dengan posisi kamera tegak (portrait). Untuk lebih jelasnya dapat dilihat pada Gambar 10 (b).

\subsubsection{Pengambilan Data Titik Kontrol dengan}

Foto Rentang Dekat

Ground Control Point (GCP) atau Titik Kontrol

Tanah merupakan objek di permukaan bumi yang dapat diidentifikasi pada foto dan memiliki koordinat
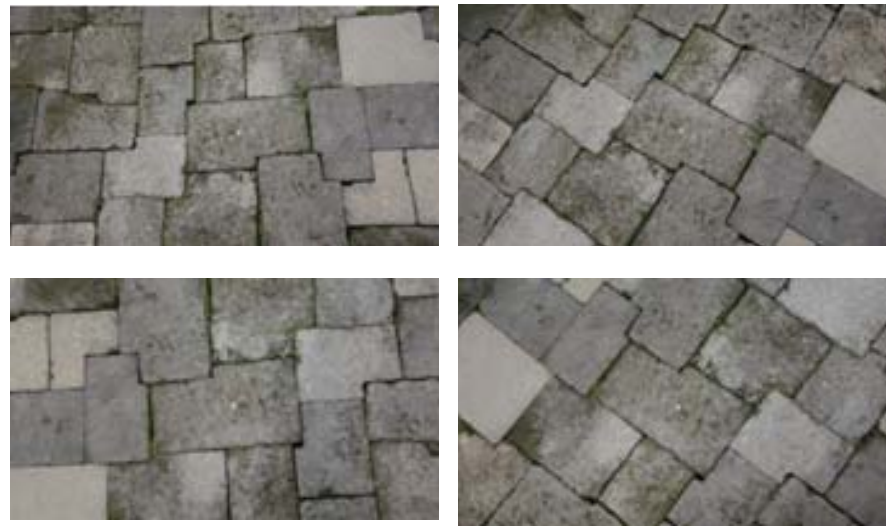
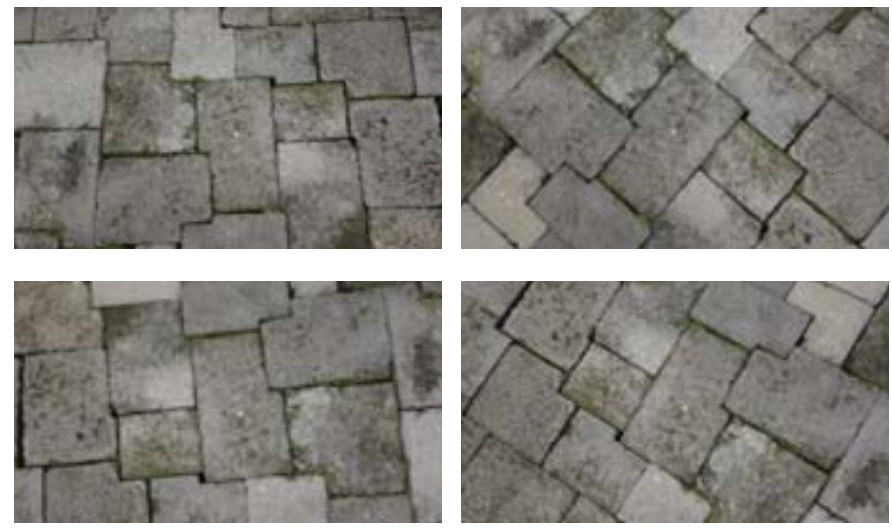

Gambar 11. Hasil Foto Titik Kontrol 


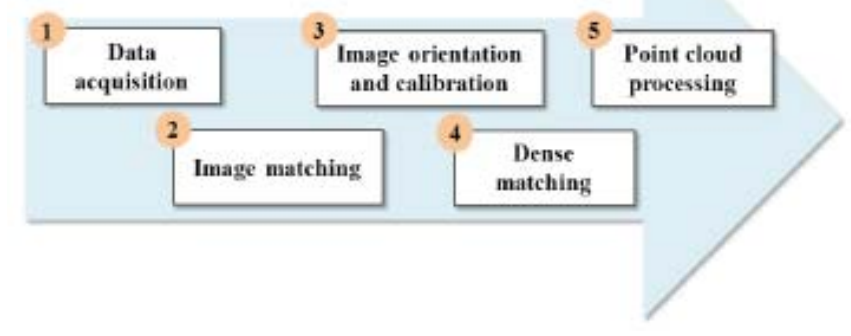

Gambar 12. Tahapan dalam Perangkat Lunak PhotoScan

bereferensi terhadap tanah (X,Y,Z). Sebuah GCP yang memiliki informasi spasial planimetrik (X,Y) serta ketinggian (Z) dinamakan GCP topografik, sedangkan GCP planimetrik hanya menyediakan informasi $(X, Y)$ dan yang menyediakan informasi ketinggian ( $Z$ ) saja disebut GCP tinggi (Raditya, 2010). Informasi GCP dapat diukur dengan menggunakan Total Station, atau GPS statik. GCP berguna sebagai kontrol posisi maupun geometri dari rangkaian foto yang sudah terikat satu sama lain dalam proses yang dinamakan Triangulasi Udara.

Selain GCP, ada juga istilah Check. Point. Independent Check Point (ICP) memiliki pengertian yang hampir sama dengan GCP yaitu merupakan titik di permukaan bumi yang memiliki koodinat (X,Y maupun $\mathrm{Z}$ ). Namun, titik ICP tidak dilibatkan dalam proses Triangulasi Udara. Titik ini hanya digunakan untuk melihat akurasi dalam pengolahan fotogrametri. Dalam melakukan menghitung error ICP dilakukan perhitungan RMSE (Root Mean Square Error) seperti pada penghitungan residu GCP.

Pengambilan data foto terrestrial dilakukan secara konvergen yaitu pengambilan foto mengelilingi titik kontrol paku dengan memposisikan objek di tengah foto. Untuk mendapatkan jaring geometri foto yang baik, dilakukan pemotretan dari 8 arah mengelilingi objek. Gambar 11 memperlihatkan salah satu contoh pemotretan titik kontrol paku secara konvergen.

\subsection{Pengolahan Data dan Pemodelan}

Pada dasarnya, pembuatan model 3D dengan mengunakan teknik fotogrametri adalah dengan terlebih dahulu mencari orientasi kamera dari masing-masing stasiun pengambilan gambar kemudian mencari posisi titik-titik pada gambar dengan menggunakan prinsip kesegarisan sehingga didapatkanlah posisi kumpulan titik-titik yang disebut point cloud. Berikut ini adalah tahapan yang dilalui dalam membentuk model 3D dengan menggunakan perangkat lunak Agisoft Photoscan, di antaranya adalah rekonstruksi orientasi foto, pembuatan dense point cloud, pembuatan mesh dan pemberian tekstur.

Photoscan adalah lanjutan solusi berbasis gambar yang dihasilkan oleh perusahaan yang berbasis di Rusia AgiSoft LLC untuk membuat tiga-dimensi (3D) konten berkualitas profesional dari gambar diam. Program ini memiliki antarmuka yang sederhana dan memungkinkan generasi jarang, titik awan padat, akurat jerat bertekstur tiga dimensi dan representasi lain seperti DSMs dan orthophotos (Verhoeven, 2011).

\subsubsection{Rekonstruksi Foto Udara dan Foto Rentang Dekat}

Rekonstruksi orientasi foto adalah langkah pertama dalam pembuatan model 3D menggunakan prinsip fotogrametri. Dalam proses rekonstruksi orientasi foto ini akan dicari posisi kamera saat pengambilan data relatif dengan objek yang akan dimodelkan. Langkah yang dilakukan adalah membuat project Agisoft dan menginput hasil pengambilan foto dari FUFK dan foto terrestrial. Seluruh hasil foto dari FUFK dimasukkan ke dalam satu sub project atau chunk. Kemudian untuk hasil foto konvergen terrestrial, setiap satu titik kontrol dimasukkan ke dalam satu chunk. Setelah semua foto dipisahkan, kemudian dilakukan align photos dari setiap chunk tersebut. Setelah semua foto telah menjalani proses align photos, akan terbentuk sparse point cloud. Gambar berikut adalah hasil dari align photos dari foto terrestrial dan FUFK.
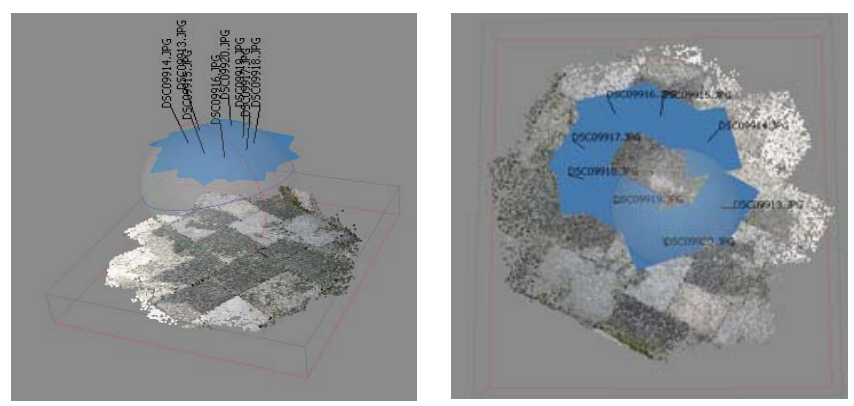

Gambar 13. Hasil Align Foto Rentang Dekat Titik Kontrol
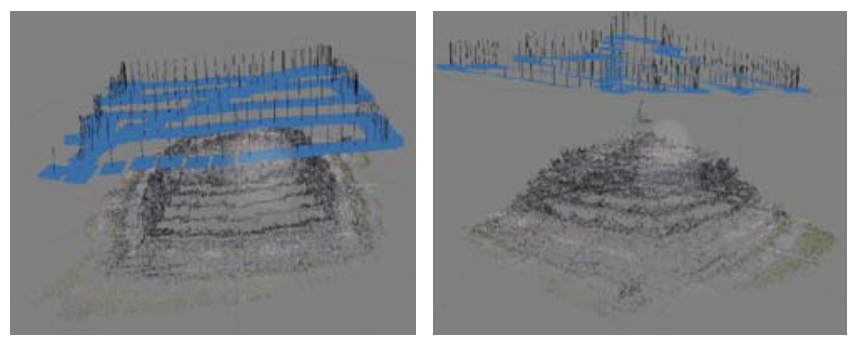

Gambar 14. Hasil Align Photos Foto Udara Format Kecil 

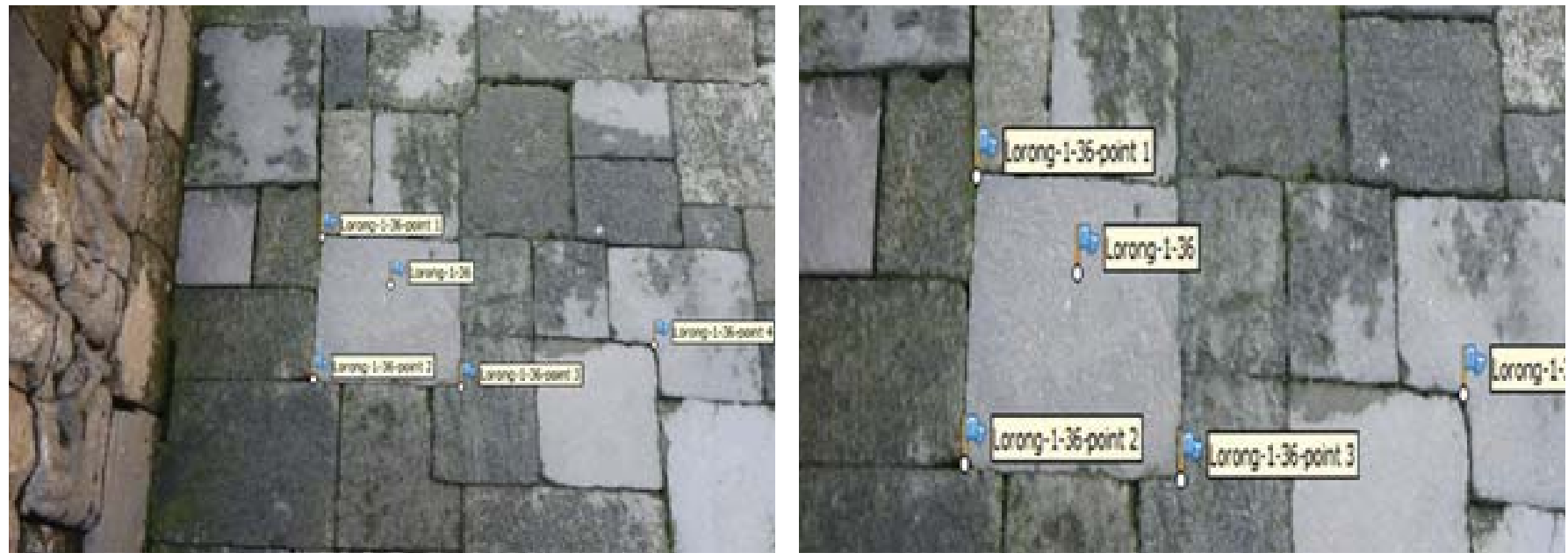

Gambar 15. Ilustrasi Marking Foto Terrestrial

\subsubsection{Identifikasi dan Rekonstruksi Titik Kontrol untuk Kontrol Foto Udara}

Dalam pekerjaan ini, proses penitikan atau identifikasi GCP dilakukan pada foto terrestrial dan FUFK. Setelah melakukan align photos pada semua foto (terrestrial dan FUFK), kemudian dilakukan penitikan pada foto terrestrial. Lokasi marker diletakkan pada tengah paku titik kontrol. Selain penitikan pada titik tengah paku, dilakukan juga penitikan 4 titik well defined point di sekitar paku tersebut. Titik well defined point dapat dibuat di batasbatas antar batu atau ujung batu. Penitikan well defined point ini dilakukan untuk dapat memudahkan penitikan pada hasil foto udara karena pada foto udara hanya sampai terlihat batas-batas batuan saja atau dengan kata lain titik well defined point ini hanya bertindak sebagai titik ikat. Penitikan dilakukan pada semua foto terrestrial agar mendapatkan hasil titik dengan akurasi yang baik. Pada gambar 15 berikut ini adalah gambar ilustrasi marking foto terrestrial.

Selanjutnya dilakukan penitikan pada foto udara. Langkah pertama yang dilakukan adalah menentukan lokasi kasar titik kontrol dengan berpatokan pada data ortofoto Borobudur yang telah diperoleh sebelumnya. Setelah menemukan lokasinya, dilakukan perbesaran pada lokasi titik kontrol yang ingin dilakukan proses marking. Kemudian dicocokkan antara pola batu lokasi titik kontrol pada foto udara dan foto terrestrial agar mendapatkan lokasi detail titik kontrol tersebut. Kemudian melakukan penitikan 4 titik well defined point sesuai dengan lokasi titik pada foto terrestrial. Penitikan dilakukan pada foto udara yang terdeteksi terdapat titik kontrol. Setiap titik tersebut harus memiliki nama yang sama dengan titik pada foto terrestrial. Langkah ini dilakukan untuk seluruh titik kontrol. Pada gambar 16 merupakan perbandingan marking pada foto udara dan foto terrestrial.

Dari hasil identifikasi titik kontrol, dari 88
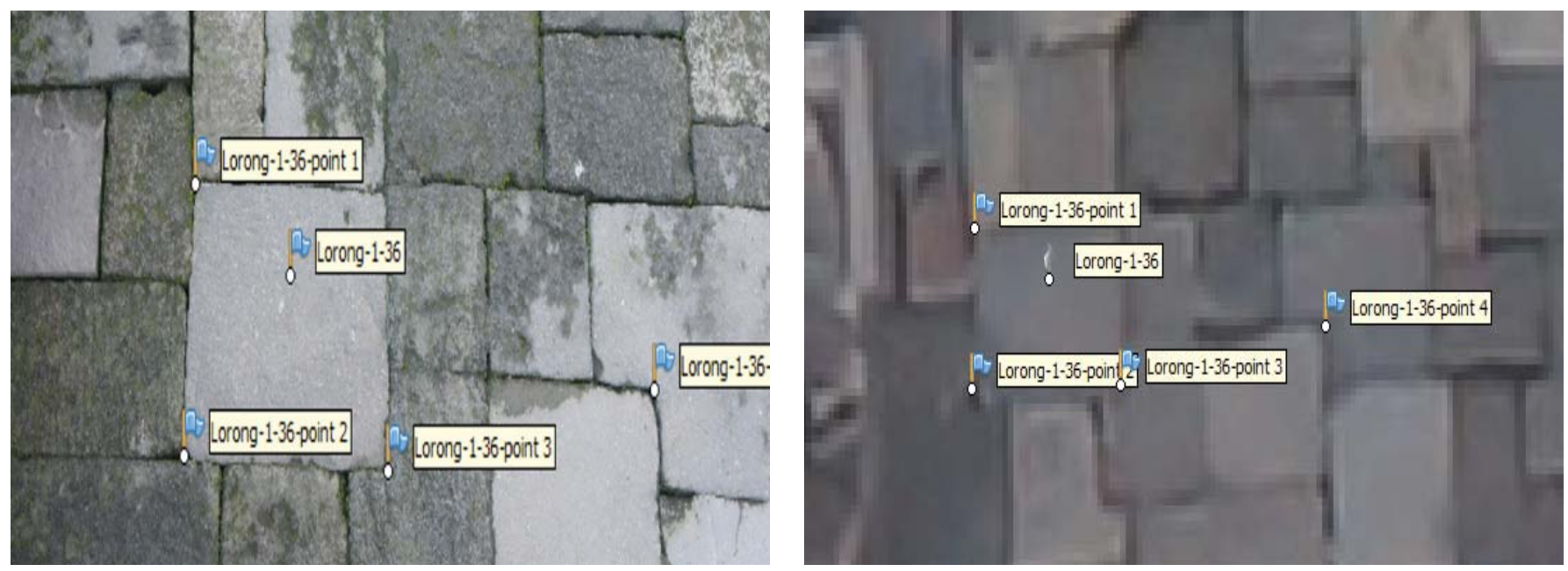

Gambar 16. Perbandingan Foto Udara dan Foto Terrestrial 

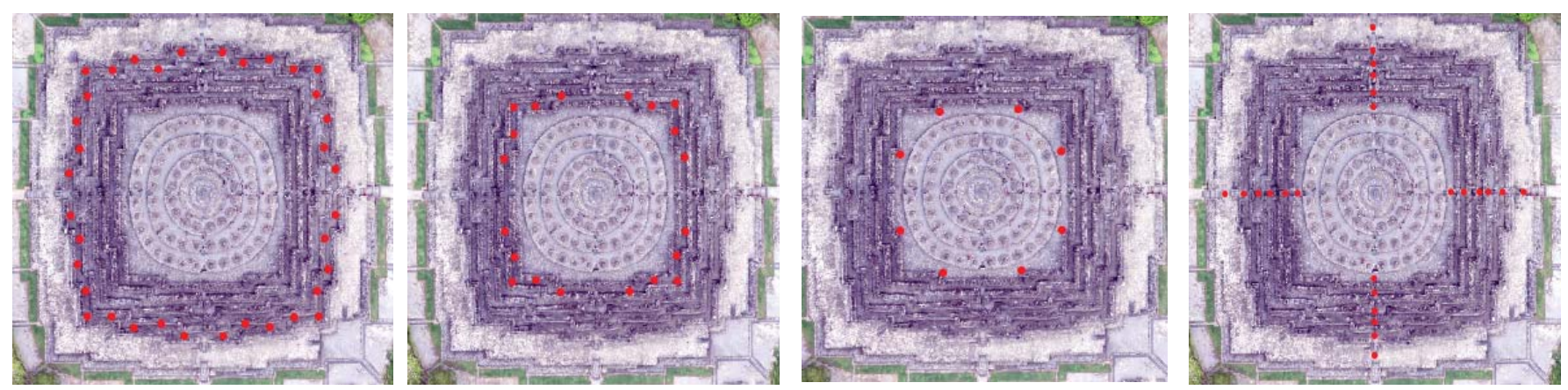

Gambar 17. Persebaran Titik kontrol pada lorong 1 (a), lorong 4 (b), lorong 5 (c), dan tangga (d)

titik hanya ditemukan 58 titik yang dapat teridentifikasi dengan baik dengan sebaran pada gambar $17 \mathrm{Hal}$ ini disebabkan karena pada proses identifikasi sebagian titik tidak ditemukan kecocokan pola dari foto udara dan foto terrestrial sehingga tidak dapat dilakukan marking. Selain itu, terkadang pada foto udara ada foto yang blur sehingga tidak terlihat jelas pola bentuk lantai Borobudur.

\subsubsection{Penggabungan Titik Kontrol}

Setelah melakukan proses marking pada foto terrestrial dan foto udara, kemudian dilakukan penggabungan titik kontrol antara kedua jenis foto tersebut. Penggabungan dilakukan agar dapat menggambarkan titik kontrol secara keseluruhan dari candi Borobudur. Langkah yang dilakukan dalam penggabungan ini adalah dengan align photos pada setiap chunk yang berisi foto terrestrial dan foto udara kemudian dilakukan merged chunk. Merged chunk dapat dilakukan apabila penamaan titik pada chunk satu dan chunk lainnya sama. Pada hasil merged chunk kemudian dilakukan align photos atau dilakukan perataan berkas kembali. Dengan melakukan perataan berkas kembali, maka akan diperoleh nilai akurasi dan residu. Hasil penggabungan chunk dapat dilihat pada gambar 18 berikut.

\subsubsection{Model Permukaan Digital}
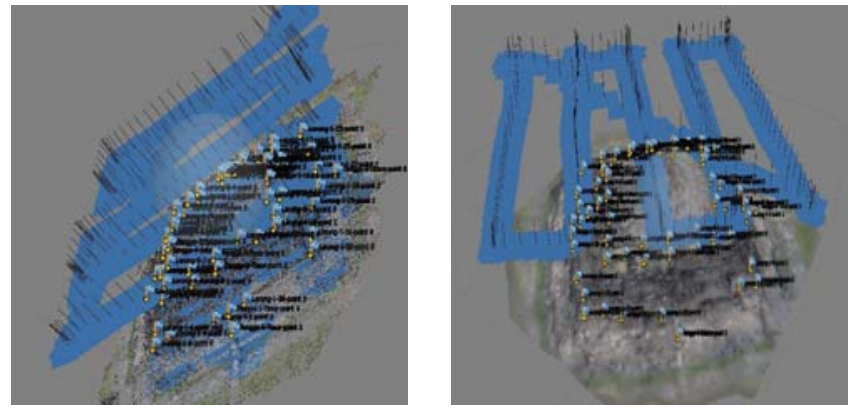

Gambar 18. Hasil Penggabungan Foto Terrestrial dan Foto Udara
Setelah didapatkan point cloud dari proses sebelumnya langkah selanjutanya adalah pembuatan mesh. Pembuatan mesh ini dilakukan untuk mebentuk model permukaan digital dari objek yang akan diteliti. Pada prinsipnya, pembuatan mesh dalam perangkat lunak Agisoft Photoscan adalah dengan membuat segitigasegitiga kecil yang saling berhubungan satu sama lainnya sehingga membentuk sebuah model permukaan (Agisoft LLC, 2013). Model permukaan yang dibentuk dari satuan segitiga-segitiga disebut juga dengan TIN (Triangulated Iregular Network). Sesuai dengan namanya TIN dibentuk dengan cara triangulasi dari titik-titik pembentuknya yang dalam kasus ini berupa point cloud (Prahasta, 2008).

\section{Hasil dan Pembahasan}

Tabel 3.1 Tabel Control Points

\begin{tabular}{lllll} 
Nama & $\begin{array}{l}\text { Error X } \\
(\mathrm{cm})\end{array}$ & $\begin{array}{l}\text { Error } \mathbf{Y} \\
(\mathrm{cm})\end{array}$ & $\begin{array}{l}\text { Error Z } \\
(\mathrm{cm})\end{array}$ & $\begin{array}{l}\text { Error } \\
\text { Total }(\mathrm{cm})\end{array}$ \\
\hline Konfigurasi 1 & 1,104 & 1,095 & 0,870 & 1,782 \\
\hline Konfigurasi 2 & 1,104 & 0,831 & 0,373 & 1,431 \\
\hline Konfigurasi 3 & 1,382 & 1,010 & 1,248 & 2,179 \\
\hline Konfigurasi 4 & 1,381 & 0,820 & 1,303 & 2,068 \\
\hline Konfigurasi 5 & 1,239 & 0,970 & 1,274 & 2,027 \\
\hline Konfigurasi 6 & 1,251 & 0,823 & 1,286 & 1,976
\end{tabular}

\section{Tabel 3.2 Tabel Check Points}

\begin{tabular}{lllll} 
Nama & $\begin{array}{l}\text { Error X } \\
(\mathbf{c m})\end{array}$ & $\begin{array}{l}\text { Error Y } \\
(\mathrm{cm})\end{array}$ & $\begin{array}{l}\text { Error Z } \\
(\mathrm{cm})\end{array}$ & $\begin{array}{l}\text { Error } \\
\text { Total }(\mathrm{cm})\end{array}$ \\
\hline Konfigurasi 1 & 1,850 & 1,423 & 3,990 & 4,626 \\
\hline Konfigurasi 2 & 1,604 & 1,416 & 3,334 & 3,962 \\
\hline Konfigurasi 3 & 1,788 & 1,314 & 3,382 & 4,045 \\
\hline Konfigurasi 4 & 1,533 & 1,287 & 2,474 & 3,192 \\
\hline Konfigurasi 5 & 1,731 & 1,208 & 3,210 & 3,842 \\
\hline Konfigurasi 6 & 1,482 & 1,147 & 2,232 & 2,915
\end{tabular}




\subsection{Pembentukkan Konfigurasi Konfigurasi GCP}

Berikut ini adalah hasil RMSE error total dari pembuatan masing-masing konfigurasi:

Nilai RMSE control points dari semua konfigurasi berkisar antara 1-2,2 cm dan hasil error check points berkisar antara 2,9-4,6 cm. Nilai tersebut cukup kecil dan layak untuk sebuah perekaman data tiga dimensi (3D). Control Points merupakan titik GCP yaitu titik yang digunakan dalam proses bundle adjustment atau perataan berkas pada Agisoft Photoscan, sedangkan check points hanya sebagai penentu akurasi pengukuran.
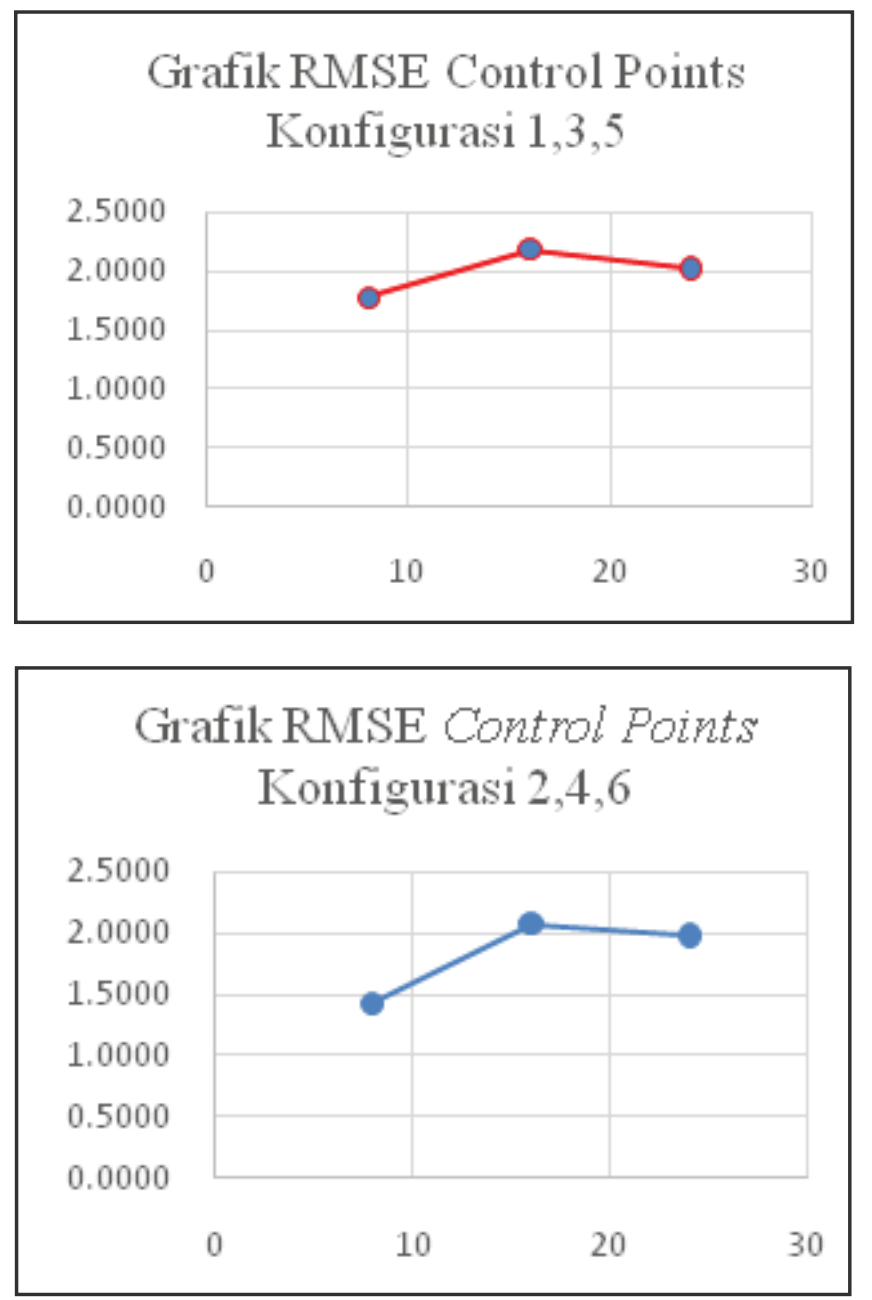

Gambar 3.2 Grafik TMSE Control Points

\subsubsection{Pengaruh Jumlah GCP}

Dari keenam konfigurasi yang dibuat, dapat dilihat bahwa semakin banyak titik yang dijadikan sebagai GCP akan menaikkan nilai RMSE control points dan menurunkan nilai RMSE check points. Untuk lebih jelasnya akan dijelaskan pada gambar grafik berikut:

Sumbu X pada grafik menunjukkan jumlah titik kontrol yang dijadikan GCP sedangkan sumbu
Y menunjukkan nilai RMSE dari control points dalam satuan sentimeter. Dari grafik ini dapat terlihat bahwa penggunaan GCP yang lebih sedikit memiliki error lebih kecil. Namun, nilai ini belum menjamin akurasi yang baik karena parameter yaitu GCP yang digunakan sedikit. Pada proses triangulasi udara, dilakukan proses perataan kuadrat terkecil yang dimana apabila semakin banyak parameter yang digunakan, maka akan menghasilkan nilai residu yang menggambarkan ketelitian pada pengukuran sehingga pada konfigurasi 1 belum dapat dijadikan nilai GCP terbaik. Pada konfigurasi 5 dan 6 dimana menggunakan lebih banyak GCP dan juga penambahan foto miring memiliki RMSE GCP lebih kecil dibandingkan konfigurasi 3 dan 4. Dari hasil ini dapat dikatakan bahwa konfigurasi 5 dan 6 lebih baik daripada konfigurasi lainnya karena memiliki parameter lebih banyak dan nilai RMSE lebih kecil.

Kemudian dari hasil RMSE check points dapat dilihat pada grafik berikut :

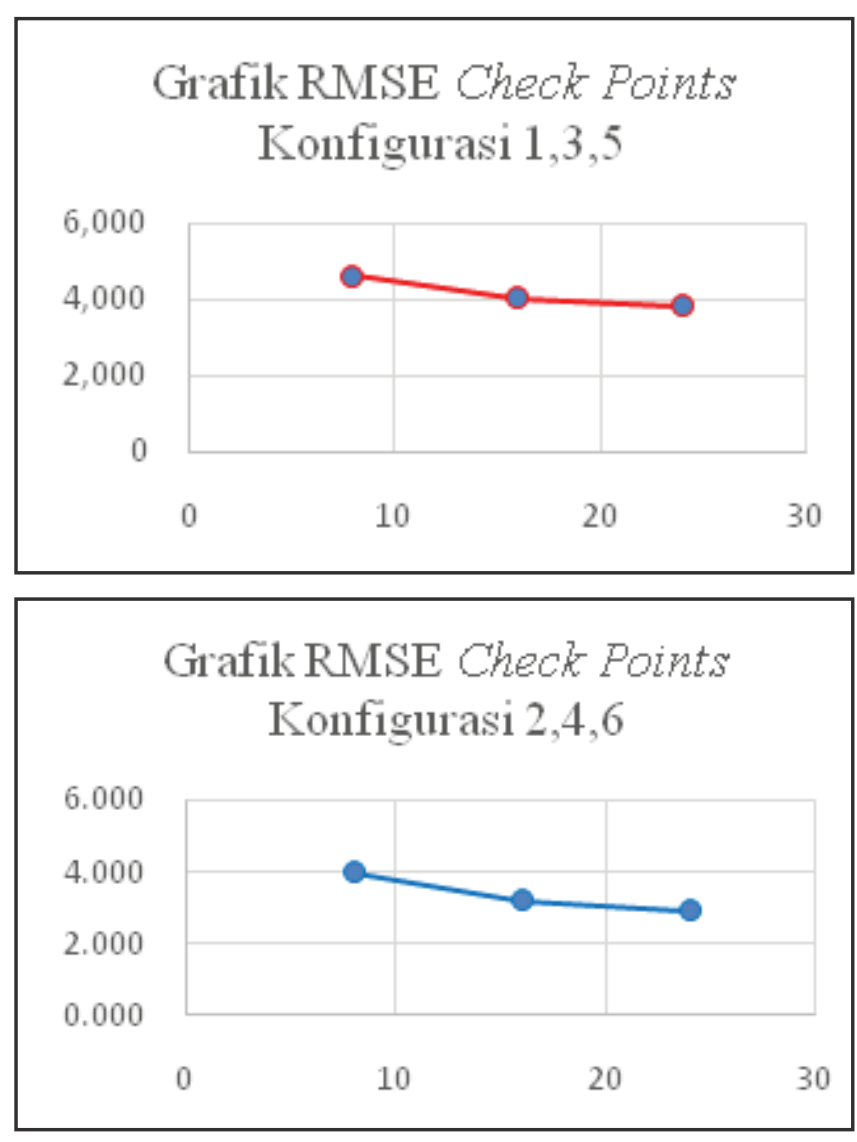

Gambar 3.2 Grafik TMSE Control Points

Dari grafik ini dapat terlihat bahwa penambahan titik GCP akan menurunkan nilai RMSE check points. Hal ini dikarenakan semakin banyak titik kontrol yang digunakan pada triangulasi udara. RMSE check points 
merupakan penentu akurasi dari produk fotogrametri yang telah diolah sebelumnya. Grafik ini menunjukkan konfigurasi 6 lebih baik dari konfigurasi lainnya karena menggunakan titik GCP terbanyak dan dengan penambahan foto miring.

Tabel 3.3 Tabel Perbandingan RMSE total Control Points foto vertikal dan vertikal + miring

\begin{tabular}{|lll} 
& Foto Vertikal & Foto Vertikal + Miring \\
\hline 8 GCP & $1,782 \mathrm{~cm}$ & $1,431 \mathrm{~cm}$ \\
$16 \mathrm{GCP}$ & $2,179 \mathrm{~cm}$ & $2,068 \mathrm{~cm}$ \\
\hline $24 \mathrm{GCP}$ & $2,025 \mathrm{~cm}$ & $1,976 \mathrm{~cm}$ \\
\hline
\end{tabular}

Tabel 3.4Tabel Perbandingan RMSE total Check Points foto vertikal dan vertikal + miring

\begin{tabular}{lll} 
& Foto Vertikal & Foto Vertikal + Miring \\
\hline 8 GCP & $4,626 \mathrm{~cm}$ & $3,962 \mathrm{~cm}$ \\
$16 \mathrm{GCP}$ & $4,045 \mathrm{~cm}$ & $3,192 \mathrm{~cm}$ \\
$24 \mathrm{GCP}$ & $3,842 \mathrm{~cm}$ & $2,915 \mathrm{~cm}$ \\
\hline
\end{tabular}

\subsubsection{Pengaruh Penambahan Foto Miring}

Untuk melihat pengaruh dari penambahan foto miring dapat dilihat pada tabel RMSE total berikut :

Dari tabel tersebut dapat dilihat dengan jumlah GCP yang sama, penambahan foto miring menurunkan nilai RMSE control points maupun check points. Hal ini dikarenakan dengan penambahan foto miring, akan semakin banyak foto yang bertampalan.

\subsubsection{Resolusi kamera dan kualitas hasil foto}

Resolusi kamera dapat mempengaruhi hasil ketelitian GCP. Kamera dengan resolusi baik, akan membuat proses identifikasi titik kontrol akan menjadi lebih baik karena akan dapat dengan mudah menemukan lokasi titik kontrol secara akurat. Pada lokakarya ini, kamera pada foto udara mempunyai ground sample distance (GSD) sebesar 1,5 cm pada foto vertikal. Dengan demikian, ketelitian akan lebih besar dari 1,5 cm. Walaupun pada titik kontrol telah diukur menggunakan ETS dengan ketelitian sampai 1,6 mm, namun karena keterbatasan resolusi kamera, akan menyebabkan ketelitian akan sama atau melebihi $1,5 \mathrm{~cm}$. Setelah dilakukan 6 konfigurasi, didapatkan konfigurasi 6 dengan menempatkan 24 GCP dan dengan penambahan foto miring adalah konfigurasi terbaik dilihat dari nilai RMSE control points total (1,976 $\mathrm{cm})$ dan RMSE check points total $(2,915 \mathrm{~cm})$. Dengan nilai ini, sesuai dengan standar pemetaan oleh ASPRS, hasil ini dapat digunakan untuk membuat peta dengan skala 1:200 (sumber : ASPRS 1998)

\section{Ketelitian Horisontal}

- Spesifikasi teknis (internasional) untuk peta yang baik: 95\% dari detail-detail planimetrik yang terdefinisi dengan baik pada foto harus diplot sehingga posisinya pada peta final tidak boleh berbeda lebih dari $0,5 \mathrm{~mm}$ pada skala peta dari posisi sebenarnya.

- Nilai RMSE horizontal yang didapat dari perhitungan RMSEx terbaik $=1,482 \mathrm{~cm}$

RMSEy terbaik $=1,147 \mathrm{~cm}$

RMSE Horisontal $=1,874 \mathrm{~cm}$

- Ketelitian horizontal untuk selang kepercayaan 95\% adalah $1,78 \times 1,874=3,4 \mathrm{~cm}$

- Untuk skala peta 1:200, batas nilai ketelitian horizontal menurut ASPRS (Tabel 3.6) adalah 0.050 meter, maka nilai ketelitian horizontal dari pemetaan ini sudah terpenuhi.

\section{Ketelitian Vertikal}

- Menurut National Mapping Accuracy Standard (NMAS), spesifikasi teknis untuk peta yang baik: 90\% dari tinggi yang ditentukan dari garis kontur yang diplot (bukan hasil interpolasi kontur) tidak boleh berbeda lebih dari 0,5 m selang kontur dari tinggi yang sebenarnya.

- Nilai RMSEz diambil dari perhitungan check points, yaitu 2,2232 cm.

- Ketelitian vertikal (VMAS) $=1,6449 \times 2,232 \mathrm{~cm}=$ $3,67 \mathrm{~cm}$

- Selang kontur untuk peta skala 1:200 adalah $10 \mathrm{~cm}$. Sehingga standar ketelitian vertikal yaitu $10 \mathrm{~cm}$ x 10 $\mathrm{cm}=100 \mathrm{~cm}$

- Dengan demikian ketelitian vertikal dari pemetaan ini sudah memenuhi standar ketelitian dengan derajat kepercayaan $90 \%$.

\section{Kesimpulan dan Saran}

Dari penelitian ini dapat diambil beberapa kesimpulan dan saran :

1. Bahwa dalam melakukan identifikasi titik kontrol pada suatu objek, dapat dilakukan dengan pengambilan foto udara dan foto terrestrial. 
Tabel 3.5 Tabel Akurasi Standar ASPRS untuk Peta Skala Besar (Horisontal) (ASPRS, 1988)

$\begin{array}{cc}\text { Class } 1 \text { Planimetric Accurcacy } & \text { Map Scale } \\ \text { Limiting RMSE (meters) } & 1: 50 \\ 0,0125 & 1: 100 \\ 0,025 & 1: 200 \\ 0,050 & 1: 500 \\ 0,125 & 1: 1000 \\ 0,25 & \end{array}$

2. Hasil uji coba konfigurasi didapatkan RMSE control points antara 1-2,2 cm dan RMSE check points antara 2,9-4,6 cm. Hasil ini tidak dapat menyamai nilai ketelitian titik kontrol yang diukur secara terrestris dengan menggunakan ETS karena keterbatasan resolusi kamera. Resolusi kamera pada penelitian (GSD) adalah 1,5 cm sehingga ketelitian yang didapatkan akan lebih besar dari nilai tersebut.

3. Sesuai dengan standar yang ditetapkan oleh ASPRS, pemetaan ini dapat digunakan untuk pemetaan dengan skala 1:200. Dengan nilai ini, hanya cukup baik untuk membuat peta foto dan kurang baik

\section{DAFTAR PUSTAKA}

De Luca, L., 2013: 3D Modelling and Semantic Enrichment in Cultural Heritage. Proc. 54th Photogrammetric Week.

Durmacay, J., 1978. Borobudur. Kuala Lumpur: Oxford University Press.

Fassi, F., Achille, C., Fregonese, L., 2011. Surveying and modelling the main spire of Milan Cathedral using multiple data sources. The Photogrammetric Record, Vol. 26(136), pp. 462- 487.

Fassi, F., Achille, C., Mandelli, A., Rechichi, F., Parri, S., 2015. A new idea of BIM system for visualization, web sharing and using huge complex $3 \mathrm{~d}$ models for facility management. International Archives of the Photogrammetry, Remote Sensing and Spatial Information Sciences, Vol. XL(5/W4), pp. 359-366

Guidi, G., Remondino, F., Russo, M., Menna, F., Rizzi, A., Ercoli, S., 2009. A multi-resolution methodology for the 3D modeling of large and complex archaeological areas. Int. Journal of Architectural Computing, 7(1), 40-55.

Gruen, A., Remondino, F., Zhang, L., 2005. The Bamiyan project: multi-resolution image-based modeling. apabila digunakan untuk membuat detail dari bagianbagian candi seperti relief, stupa atau gapura.

4. Untuk membuat detail bagian-bagian candi tersebut, dibutuhkan pengukuran lebih teliti seperti membuat titik kontrol pengukuran dengan ETS atau pengukuran lapangan seperti dengan pita ukur pada objek yang ingin dibuat modelnya secara detail dan pengambilan foto rentang dekat dari objek yang ingin dibuat model 3 dimensinya.

5. Hal-hal yang mempengaruhi kualitas titik kontrol adalah jumlah titik kontrol, banyaknya pertampalan pada foto, resolusi kamera dan kualitas hasil foto. Konfigurasi terbaik dari pengujian 6 konfigurasi adalah konfigurasi 6 dengan RMSE control points dan check points $1,976 \mathrm{~cm}$ dan $2,92 \mathrm{~cm}$.

6. Perapatan titik kontrol untuk memodelkan objek dengan menggunakan metode fotogrametri terrestrial dan foto udara, dibutuhkan kamera dengan resolusi lebih tinggi terutama pada foto udara sehingga pada proses penitikan akan menghasilkan kualitas GCP yang sangat baik.

In: Recording, Modeling and Visualization of Cultural Heritage, Taylor \& Francis / Balkema, ISBN 0415 39208 X, pp. 45-54.

Kochi, N., Kitamura, K., Sasaki, T., Kaneko, S., 2012. 3D Modeling of architecture by edge-matching and integrating the point clouds of laser scanner and those of digital camera. International Archives of Photogrammetry and Remote Sensing and Spatial Information Sciences, Vol. 39(B5).

Kwee, M. G., 2012. The Borobudur: A Psychology of Lovingkindness Carved in Stone. (K. Dhammasami, \& D. Peoples, Eds.) The Journal of International Association of Buddhist Universities, 1-28.

Kraus, K., 1997. Photogrammetry. Volume 2: Advanced Methods and Applications. Ferd-Dümmlers Verlag. Hullo, J. F., Thibault, G., Boucheny, C., 2015. Advances in Multi-Sensor Scanning and Visualization of Complex Plants: the Utmost Case of a Reactor Building. International Archives of the Photogrammetry, Remote Sensing and Spatial Information Sciences, Vol. XL(5/W4), pp. 163-169. 